\title{
Maryja jako grecko-rzymski ideał kobiety
}

\author{
Mary as the Graeco-Roman Ideal of a Woman
}

\author{
ROBERT K. ZAWADZKI \\ Uniwersytet Humanistyczno-Przyrodniczy im. Jana Długosza w Częstochowie \\ r.zawadzki@ujd.edu.pl, ORCID: 0000-0001-6964-1736
}

\begin{abstract}
Streszczenie: Artykuł stanowi omówienie moralnego, religijnego i literackiego podłoża kultury grecko-rzymskiej, na którym przejawiał się i rozwijał kult Maryi. Tekst zawiera przegląd tytułów Maryi, takich jak: Matka Boża, Dziewica, Wspomożycielka, Matka Bolesna, Madonna z Dzieciątkiem, rozpatruje związek tych nazw z pewnymi aspektami grecko-rzymskiej kultury, analizuje reakcję pogan na ujawnienie się licznych godności Maryi, wskazuje, że miały one precedensy w kulturze Greków i Rzymian, którzy cechowali się swoistym przygotowaniem na przyjęcie kultu Maryi. Artykuł przedstawia najwcześniejszy etap rozwoju kultu maryjnego, ze szczególnym uwzględnieniem kontekstu kultury grecko-rzymskiej.
\end{abstract}

Słowa kluczowe: kult maryjny, tytuły Maryi, kultura grecko-rzymska, mariologia, chrześcijaństwo

Abstract: The article discusses the Graeco-Roman moral, religious, and literary context within which Mary's cult was expressed and developed. It offers an analysis of Mary's titles used together with her name, focusing on their relationship to the same aspects of the Graeco-Roman culture, and how the Mother of God as the Virgin, Lady of Consolation, Lady of Sorrows, and Madonna was perceived by the pagans. It demonstrates that this extolling of Mary's virtues, however unlikely when applied to her, did have some precedents in the culture of Greeks and Romans who were prepared to accept Mary's cult. The article sheds light on the early development of Mary's cult to seek to relate doctrine or dogma about Mary to the Graeco-Roman surroundings.

Keywords: cult of Mary, titles of Mary, Graeco-Roman culture, Mariology, Christianity

Błędem byłoby oczywiście widzieć w Maryi boginię czy jakąś antyczną bohaterkę i heroinę. „Maryja jako grecko-rzymski ideał kobiety” - to określenie kumulujące syntetycznie szereg cech charakterologicznych i sugestii, że była to osoba wyjątkowa, łącząca w sobie ideały nowej, Chrystusowej wiary ze wzorcami postępowania obowiązującymi w grecko-rzymskim antyku ${ }^{1}$ Niewiasta, choć wywodząca się z kręgu kultury Izraela, to jednak świetnie pasująca do wyobrażeń mieszkańców Imperium Romanum o kobiecej doskonałości jako Matka zarazem Boga i ludzi, opiekująca się

1 Podstawowym opracowaniem dotyczącym relacji między chrześcijaństwem w jego aspekcie mariologicznym a pogańskim światem jest dzieło Stephana Benko The Virgin Goddess, zawierająca obfity materiał faktograficzny. Autor przyznaje Maryi szczególną rangę (chyba jednak zbyt wysoką, bo w istocie boską), określając ją mianem „the feminine face of God”, mariologia to dla niego „a progression toward a clearer and better understanding of the feminine aspect of the divine and the role of the female in the history of salvation" (ibidem, 7-8). 
każdym człowiekiem, przedstawiająca mu perspektywy wspaniałego życia i zbawienia, a jednocześnie zawsze Dziewica posiadająca Dziecko, poczęte bez udziału mężczyzny, co - jak się przekonamy - wcale nie było takie trudne do przyjęcia dla wszystkich tych, którzy wychowali się na opowieściach mitologii greckiej. Nie mamy tu zamiaru szukać w kulturze grecko-rzymskiej² źródeł czy korzeni kultu maryjnego ${ }^{3}$, chcemy tylko zwrócić uwagę na fakt, że w tej cywilizacji, na której obszarze zaczęło rozwijać się chrześcijaństwo, tkwiły pewne pierwiastki ułatwiające rozprzestrzenianie się owej czci, jaką wobec Bogarodzicy żywili zarówno prości ludzie, jak i znani pisarze starochrześcijańscy.

Bo nie ulega wątpliwości, że już u zarania chrześcijaństwa Maryja, podobnie jak jej Syn - Jezus, miała rzesze czcicieli rekrutujących się przecież z pogan przedstawicieli helleńskiego i rzymskiego kręgu cywilizacyjnego ${ }^{4}$. Świadczą o tym wypowiedzi najstarszych ojców Kościoła ${ }^{5}$ takich jak Ignacy Antiocheński, Justyn, Ireneusz ${ }^{6}$, Hipolit ${ }^{7}$, Atanazy, Ambroży. Łączy ich wspólne przekonanie o Bożym macierzyństwie Maryi, przeświadczenie o jej dziewictwie, świadomość powszechności jej kultu. Powszechności, to znaczy pewnej popularności tej osoby wśród ludu, którego żarliwa wiara zaczęła przebijać do dzieł wielkich teologów ${ }^{8}$. Kontestatorzy starochrześcijańskiej pobożności maryjnej kwestionują jednak masowość tego zjawiska, wskazując na brak zainteresowania osobą Matki Chrystusa u ojców Kościoła. Wielu badaczy nie podziela tego radykalnego poglądu, jest to bowiem rzecz dziś w nauce w zasadzie bezsporna ${ }^{10}$. W pismach wymienionych wyżej autorów, jak również w wypowiedziach Grzegorza Teologa, Jana Złotoustego, Bazylego Wielkiego, Efrema Syryjczyka pojawia się sekwencja związanych ze sobą ściśle, a w końcu usankcjonowanych postanowieniami Soboru Efeskiego z 431 roku oraz Soboru Konstantynopolitańskiego II z 553 roku tytułów Maryi, jak Theotokos

2 Dla potrzeb niniejszych wywodów dokonujemy pewnego uproszczenia: będziemy się posługiwali ogólnym terminem „grecko-rzymski”, choć należy pamiętać, że cywilizacja grecka i rzymska to dwie oddzielne dziedziny, traktowane jednak często jako swoista całość. Tak właśnie razem omawia je np.: Kumaniecki, Historia.

3 Inaczej te relacje widzi Benko (The Virgin Goddess, 9), dla którego w kulcie Maryi „there is a direct line, unbroken and clearly discernible, from the goddess-cults of the ancients to the reverence paid and eventually the cult accorded to the Virgin Mary". Pogląd, moim zdaniem, zbyt radykalny. Chrześcijaństwo, owszem, czerpało z dziedzictwa antycznego, nie był to jednak jedyny i wyłączny kierunek oddziaływań. Ogólnie o kulcie Maryi zob.: Beinert - Petri, Handbuch der Marienkunde; Maciołka, „Imię Maryja. II. W liturgii”, 67; Kuźmak, „Imię Maryja. III. Bractwa”, 67-68; Rubin, Mother of God. O kulcie Maryi w Polsce: Bracha, „Zarys historii mariologii polskiej”, 459-469; Mazurkiewicz, Z dawnej literatury maryjnej.

4 Zob. Starowieyski, „Maryja w pierwszych wiekach”, 3-13; Gambero, Mary and the Fathers.

5 Fernández, „Aktualność i wartości mariologii”, 73-91.

6 Starowieyski, „Tytuł Theotokos", 412-449.

7 Rahner, „Die Marienkunde”, 137-182.

8 Zob. Starowieyski, „Tytuł Theotokos”, 412; Starowieyski, „Najstarszy opis mariofanii”, 735-744.

9 Fernández, „Aktualność i wartości mariologii”, 74.

10 Zob. Santorski, „Maryja w nauce Ojców Kościoła”, 927-937. 
i Aeiparthenos ${ }^{11}$. Przyjmuje się, że te nazwy, uzasadnione zresztą przekazem Ewangelii, funkcjonowały najpierw w środowisku pierwszych chrześcijan - ludzi częstokroć o wrażliwości helleńskiej czy rzymskiej, podatnych na przyjęcie nowej wiary, której zasady wcale nie były odległe od tego, co głosili antyczni myśliciele i filozofowie.

Tezę o swoistym przygotowaniu chrześcijaństwa przez religię hellenizmu, czyli o wyjątkowości greckiego doświadczenia religijnego, jego metafizycznej głębi i wrażliwości na prawdę, dobro i piękno, próbował już prawie sto lat temu głosić Tadeusz Zieliński - jeden z najwybitniejszych znawców antyku. Twierdził on, że kultura helleńska przygotowała ludzkość do przyjęcia chrześcijaństwa, że religia grecka stanowi prawdziwy Stary Testament nowego wyznania, bo obudziła w ludziach potrzeby, które mogły z czasem znaleźć swe wypełnienie w chrześcijaństwie ${ }^{12}$. Choć niektórzy dzisiejsi uczeni krytykują ustalenia Zielińskiego ${ }^{13}$, skłonny byłbym jednak stanąć po stronie tych, którzy zgadzają się z tym badaczem, że w pewnym zakresie hellenizm stanowi rzeczywiście przygotowanie ludzkości do przyjęcia chrześcijaństwa ${ }^{14}$. Chodzi tu zwłaszcza o filozofię ${ }^{15}$, pojętą jako etykę i metafizykę, uprawianą od czasów Sokratesa, Platona, Arystotelesa aż po stoików. Religia grecka z kolei była wprawdzie politeistyczna i lansowała niekiedy niemoralne - z punktu widzenia chrześcijaństwa - zachowania, jednocześnie rejestrowała jednak zarówno pewien transcendentny wymiar miłości, jak i niosła elementy uniwersalistycznego myślenia. Te okoliczności ułatwiły przyjęcie chrześcijaństwa z całym jego przesłaniem, także szacunkiem należnym Maryi jako Matce Chrystusa ${ }^{16}$.

Wracając do zasadniczej tezy tego artykułu, przez nawiązanie do pewnych zjawisk tkwiących w starożytnej kulturze będę usiłował wykazać, że hellenizm, czy szerzej - dziedzictwo grecko-rzymskie, przyzwyczaiło ludzkość do pewnego kobiecego statusu i ideału, ułatwiając jej przez to zaakceptowanie kultu maryjnego.

11 Gwoli ścisłości. Zasada wiary dotycząca tytułu Theotokos (Boże Macierzyństwo Maryi) została ogłoszona jako dogmat w kontekście sporów chrystologicznych podczas Soboru Efeskiego, termin Aeiparthenos pada zaś po raz pierwszy podczas obrad Soboru Konstantynopolitańskiego II. Dziewictwo Maryi (Semper Virgo) zostało ogłoszone oficjalnie jako dogmat dopiero przez papieża Marcina I na Synodzie Laterańskim w Rzymie w 649 roku. Ogólnie o soborach zob. Ćwik, „Kształtowanie się dogmatów” 31-47. Zob. też: Santorski, „Maryja w nauce Ojców Kościoła”, 927-937; O’Carroll, Theotokos, 24-31; Zawadzki, „Kim jest oblubieniec", 367-371.

12 Zob. Zieliński, Religia starożytnej Grecji, 267.

13 Opinie krytyczne relacjonuje Maria Dzielska („Kierunki badań nad historią religii”, 277-291).

14 Zob. na ten temat: Esler, „The Mediterranean Context”, 5-25. Zob. też: Peters, The Harvest of Hellenism; Jeffers, The Greco-Roman World; Musiał, Antyczne korzenie; Johnson, Among the Gentiles.

15 Zob. Martin, „Graeco-Roman Philosophy”, 53-79.

16 Świat pogański nie zawsze odnosił się entuzjastycznie do chrześcijaństwa. Prześladowania są tego dowodem. O różnych aspektach tej niechęci zob. Kręcidło, „Świat pogański”, 282-291. 


\section{Antyk i kobiety}

Antyk nie był tylko manifestacją geniuszu mężczyzn, ale dostarczył także wiele przykładów talentów płci pięknej. Kobiety starożytności to przecież poetki z Safoną ${ }^{17}$ na czele, niekwestionowane mistrzynie wiersza, wynalazczynie nowych miar metrycznych, imitatorki śpiewu ptaków i innych dźwięków przyrody. Wobec tego bogactwa nikt nie pozostaje obojętny: mistrzostwo formy, znakomitość obrazowania, bezbłędność metaforyki, krótko mówiąc - doskonałość. Nic dziwnego, że ta kategoria w kulturze greckiej i rzymskiej nie była zarezerwowana tylko dla mężczyzn, lecz stała się także udziałem kobiet.

Ich świat zorganizowany był przez szereg zasad moralnych regulujących życie, postępowanie, relacje $z$ innymi ludźmi ${ }^{18}$. Czuwała nad tym wszystkim bogini Hera, surowa opiekunka czystości ślubów, chroniąca „klucze małżeństwa” ${ }^{19}$, dbająca o prawa mężatek ${ }^{20}$, sprzeciwiająca się postawom amoralnym męża czy żony ${ }^{21}$. Normy, jakie reprezentowała, służyły pozycji kobiety, nie były wyprane z wszelkich etycznych wartości ${ }^{22}$. Były wśród nich: wierność i uczciwość, czystość małżeńska, dezaprobata wobec rozwodów. Przyzwolenie na rozstanie małżonków (wszakże pod pewnymi warunkami ${ }^{23}$ ), nie odtwarzało może bardzo wysokich standardów moralnych, obowiązujących $\mathrm{w}$ chrześcijaństwie, ale ich pewne znamiona pozwalają się w tej cywilizacji wyśledzić, one dziś dają się słyszeć, czuje się je. Wrażliwość etyczna człowieka wychowanego w kulturze grecko-rzymskiej została więc zorganizowana i skierowana w określonym kierunku, tyle że nie mógł go prowadzić ku religii mojżeszowej. Ta preferująca mężczyzn, których przedstawicielom Jahwe przekazywał swą naukę - nie przyznawała kobietom wysokiej pozycji ${ }^{24}$. Te zresztą, których postaci znane są z Biblii, nie zasługiwałyby na szacunek Rzymian i Greków z wielu względów. Przyjrzymy

17 Zob. Winniczuk, Twórczość poetek greckich.

18 O obyczajowości Greków i Rzymian zob. Winniczuk, Ludzie, zwyczaje i obyczaje; zob. też: Bieżuńska-Malowist, Kobiety antyku.

19 Wartość miłości małżeńskiej podkreślał już Homer, który takie słowa wkłada do ust Odyseusza przemawiającego do Nauzykai (Homerus, Odyssea 6, 181-186 [Siemieński, 78]): „Skarb to najcenniejszy w świecie, gdy małżonka z małżonką zgodna miłość splecie, duch jeden włada domem; wróg na to się krzywi, cieszą druhy! A oni nad wszystkich szczęśliwi!".

20 Nawet „mizoginista” Hezjod stwierdza, że warto mieć żonę (Hesiod, Theogonia 603-611 [Hezjod, Narodziny Bogów, 83]): „Kto ucieka od małżeństwa i przywar kobiecych i nie chce się żenić, ten doczeka żałosnego wieku, pozbawiony na starość opieki".

21 Arystofanes, Thesmoforie 976n (Arystofanes, Komedie, II, 56). Na ten temat zob. Zieliński, Hellenizm a judaizm, 149.

22 W małżeństwie tą wartością była miłość. Już Homer podkreśla ten aspekt. U niego mówi Achilles (Homer, Iliados 9, 341-342 [Dmochowski, 117]): „Przecież, każdy, kto prawym jest mężem i duch w nim stateczny, żonę swą kocha i darzy ją czułą opieką”.

23 O rozwodach zob. Jurewicz - Winniczuk, Starożytni Grecy i Rzymianie, 25-27.

24 Przykładem owego lekceważenia kobiet jest modlitwa rabina Meira (II w. po Chr.): „Bądź pochwalony, wiekuisty Boże, Władco świata, żeś mnie nie stworzył kobietą”. Inaczej traktują kobiety ewangeliści, którzy zauważają niewiasty i podkreślają, że Maryja była obecna pod krzyżem i w Wieczerniku. 
się im w dalszej części artykułu, tu tylko skonstatujmy, że spośród kobiet, których postaci przewijają się przez historię zbawienia i na kartach Biblii, właściwie tylko Maryja mogła zdobyć poważanie u Greków i Rzymian, właśnie ze względu na swoją etyczną doskonałość.

Niewiasty Starego Testamentu - czy nawet te, w jakimś sensie wyróżnione i nobilitowane ${ }^{25}$ - w oczach Greków i Rzymian to osoby, z których każda dopuściła się jakiegoś czynu niegodziwego; te wymienione w genealogii samego Chrystusa (Mt 1,1-6) to w gruncie rzeczy kobiety nie do końca moralne ${ }^{26}$. Tymczasem antyk grecko-rzymski, choć znał negatywne wizerunki kobiet w osobach Medei, Klitajmestry, Fedry, czy też wyśmiewał się z niewieściego rodu w wierszykach Archilocha i Hipponaksa, to jednak pozostawił świetlane obrazy Hekabe, Andromachy, Penelopy, Arete, Nauzykai, Alkestis, Ifigenii, Lawinii i tylu innych, bo cenił - jak już mówiliśmy - takie wartości, jak: miłość, wierność, poświęcenie i czystość. Opowieści o kobiecych zbrodniach nie były tutaj aprobatą dla takich postępków, lecz przestrogą, potępieniem.

Nie należy jednak sądzić, że jedynie literatura piękna i mitologia lansowały kobiece ideały. Są i inne świadectwa, o charakterze bardziej społecznym, socjologicznym i politycznym, dowodzące, że kobiety w kulturze grecko-rzymskiej miały swoją pozycję i rangę. Mogły być kapłankami, obywatelkami, przedsiębiorczyniami, miały swoje święta państwowe, niedostępne dla mężczyzn, w wielu dziedzinach cieszyły się równouprawnieniem. Ogromną rolę odegrała tu również religia, wiara w to, że pewnymi dziedzinami życia, a nawet całymi organizmami państwowymi opiekują się poszczególne boginie. Działanie tego zjawiska było jednokierunkowe, popularyzując daną boginię, jednocześnie stawiało ją za wzór. Na przykład łatwo było zobaczyć ideał w Atenie, nieodrodnej córze Dzeusa, działała bowiem ona zawsze mądrze, z natury swojej była dziewicą, a zarazem opiekunką i strażniczką, czyli właśnie ucieleśniała doskonałość.

25 Dla Greków i Rzymian więzi rodzinne miedzy ludźmi stanowiły bardzo często podstawę ich chwały i sławy. W przypadku rodowodu Chrystusa sprawa jest bardziej złożona. Według dzisiejszych badaczy umieszczenie w rodowodzie Chrystusa imienia danej osoby nie świadczyło o jej nobilitacji. W genealogii Jezusa znalazły się bowiem postaci (mężczyźni i kobiety), które nie powinny się tam pojawić ze względów moralnych i z racji pochodzenia (spoza Izraela). Historia rodu Jezusa ujawnia uniwersalność tej genealogii, wszechstronność i powszechność następstw pokoleń i związków pokrewieństwa, nie dowodzi natomiast szlachetności poszczególnych członków tego rodu i nie stawia ich jako wzoru do naśladowania. Zob. Malina, „Kobiety w genealogii Jezusa”, 109-111; Ordon, „Kobiety w genealogii Jezusa”, 247-249.

26 Tak właśnie kobiety wymienione w genealogii Jezusa oceniali również pisarze starochrześcijańscy, np. św. Hieronim i św. Jan Chryzostom. Dzisiaj odchodzi się od takich jednoznacznych interpretacji. Współcześni badacze wskazują na ówczesne realia, wyjątkowość położenia, niezwyczajne okoliczności, w jakich znalazły się owe kobiety. Zdaniem uczonych nie bez znaczenia dla właściwego zrozumienia ewangelicznego tekstu pozostaje także fakt interwencji Boga w życie tych niewiast. O wieloaspektowej problematyce obecności kobiet w genealogii Jezusa, wymiarze moralnym ich postępowania, znaczeniu w tradycji Izraela zob.: Malina, „Kobiety w genealogii Jezusa”, 109-129; Ordon, „Kobiety w genealogii Jezusa", 247-256. 
Ta stosunkowo wysoka pozycja kobiet i bogiń, które w świecie grecko-rzymskim były szanowane i czczone, ułatwiła niewątpliwie zaakceptowanie przez tych ludzi osoby Maryi.

\section{Maryja i kobiety Starego Testamentu}

Inaczej ta sprawa przedstawiała się $\mathrm{w}$ tradycji żydowskiej, poważającej kobiety, które - jak już sugerowaliśmy - nigdy nie zasługiwałyby na szacunek w oczach Greka i Rzymianina ${ }^{27}$, gdyż często wspólnym mianownikiem postępowania tych niewiast był swoisty relatywizm, sprowadzający się do przekonania, że zły czyn traci swą niegodziwość, jeśli dokonywany jest dla korzyści domu Izraela. Można tu przywołać przykład Rachab - wymienionej w rodowodzie Jezusa nierządnicy. Była to najszkodliwsza postać z punktu widzenia mieszkańców Jerycha, bo to ona ułatwiła Izraelitom zdobycie miasta (Joz 2,1-14) i w rezultacie przyczyniła się do wymordowania swych ziomków. Może więc dla Żydów grała pozytywną rolę, ale dla Greków i Rzymian - jak najgorszą. Jawiła się im jako zdrajczyni ${ }^{28}$. Dla nich zresztą kobieta prostytuująca się nie zasługiwała na szacunek nawet wtedy, gdy stosując wyuzdany podstęp, starała się zdobyć względy mężczyzny, by zostać jego żoną.

Jako inny przykład można podać Moabitkę Rut (Rt 3,1-18), prababkę Dawida, wymienioną również w genealogii Jezusa, wobec której Grek czy Rzymianin także wytoczyć by mógł (choćby ze względów estetycznych) nieco oskarżeń. Kobieta umyta i namaszczona olejem, odziana tylko w płaszcz (biblijny autor nie mówi, że miała na sobie coś jeszcze), idąca do starego, śpiącego, najedzonego i pijanego Booza, odkrywająca miejsce przy jego nogach ${ }^{29}$, kładąca się..., mogła w tych okolicznościach wydawać się równie sprośna jak meretrix ${ }^{30}$. W dodatku jej teściowa - Noemi, namawiająca swą synową do tego postępku, zyskuje cechy stręczycielki, bez względu na to, jaki cel chciała osiągnąć.

27 Jeszcze raz pragnę zaznaczyć, że nie jest moim zamiarem omawianie starotestamentowych kobiet z punktu widzenia dzisiejszej egzegezy biblijnej i tradycji Izraela. Na te postaci chciałbym spojrzeć oczami Greka lub Rzymianina, który przyjmując wiarę chrześcijańską, fascynował się osobą Maryi, a teksty biblijne czytał przez pryzmat swojej kultury.

28 Zdrada już u Homera piętnowana jest jako występek. Zob. opis zdradzieckiego strzału Pandara w czwartej księdze Iliady. Odrażającym przykładem zdrajcy był również Efialtes, który w czasie bitwy pod Termopilami w 480 r. przed Chr. przeprowadził wojsko perskie ścieżką górską na tyły Greków i w ten sposób przyczynił się do ich klęski. Około 10 lat potem został zamordowany; jego mordercę Spartanie czcili jako bohatera.

29 Niektórzy badacze uważają, że termin „nogi” jest prowokacyjny, stanowi w istocie eufemistyczne określenie męskiego członka. Zob. Brown - Fitzmyer - Murphy, Katolicki komentarz biblijny, 240.

30 Dziś nie ocenia się tak radykalnie Moabitki Rut. Jej postępowanie w kontekście obecnych czasów omawia interesująco Grzegorz Ryś (Rut Moabitka krewna Boga). 
Grecy i Rzymianie prawdopodobnie mieliby więc do owych niewiast stosunek negatywny, może szyderczy, może potępiający. Irytowaliby się zapewne również postaciami dwóch pozostałych kobiet wymienionych w rodowodzie Chrystusa. Tamar Kananejka (Rdz 38,1-6), najpierw żona Era i Onana, później występująca w przebraniu nierządnicy, wykazała, że kobiecy wdzięk może uwieść wdowca, a nawet teścia. Skoro osiągnęła to przez oszustwo i prowokację, to już dowiodła - w świetle greckiej arete czy rzymskiej virtus - że była osobą niegodziwą.

Ostatnia umieszczona w genealogii Jezusa kobieta - matka Salomona - to w istocie wiarołomna żona, przyczyniająca się pośrednio do śmierci swego prawowitego męża. Wobec tej niewiasty nasunęłaby się Grekowi i Rzymianinowi wątpliwość, czy

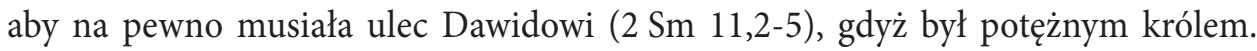
A może jednak ona powinna się przeciwstawić? Ci, którzy mieli w pamięci przykład Penelopy, opierającej się bezczelnym zalotnikom przez 20 lat, nie znaleźliby prawdopodobnie usprawiedliwienia dla Batszeby, bo tu właśnie chodziło o wierność małżeńską, streszczającą się w ślubnych słowach wypowiadanych przez Rzymianki: Ubi tu Caius, ibi ego Caia.

Rzecz ciekawa, wszystkie cztery kobiety wymienione w rodowodzie Jezusa w jednym są do siebie podobne - wszystkie dopuściły się jakichś ekscesów erotycznych, wszystkie w jakimś zakresie są meretrices ${ }^{31}$. Oczywiście ich uroda, wygląd zewnętrzny mogły podobać się Grekom i Rzymianom, biografie tych niewiast mogły zaciekawiać mieszkańca Imperium Romanum, ale gdy przeczytali opis ich czynów, wyszczególnienie czynów, które popełniły, do czego doprowadziły, na czym polegało ich postępowanie, zasadzające się na swoistym dążeniu do celu bez względu na rodzaj zastosowanych metod, mogli zwątpić o reputacji biblijnych bohaterek, bo przecież we własnej kulturze znajdowali szlachetne przykłady kobiecej czystości, wierności i ofiarności.

Być może, że stosunek Greków i Rzymian do wizerunków Rachab, Rut, Tamar i Batszeby był - podobnie jak stosunek do tragicznych protagonistek dramatów Eurypidesa czy Seneki - naznaczony przekonaniem, że charakter zwichnięty, „z robakiem w duszy" ${ }^{32}$, ogarnięty fatalną namiętnością, sprowadzał zawsze destrukcję i zagładę. Powodowani tym przekonaniem, oddając się pasjonującej lekturze Biblii, woleli śledzić szokujące losy starotestamentowych niewiast, niż starać się zrozumieć izraelską mentalność, przyzwalającą na naganne - $\mathrm{z}$ ich punktu widzenia - zachowania.

Charakterystycznym przykładem może być tu kolejna para sławnych, biblijnych bohaterek - Judyta i Estera. Są to tzw. typy Maryi, prefiguracje, postaci alegoryczne, które przyczyniły się do zwycięstwa nad złem, uratowały lud Boży od zagłady,

31 Według nauki Kościoła powierzenie wielkich zadań człowiekowi przez Boga, świadczy o Jego wspaniałości. Stwórca wbrew ludzkim oczekiwaniom wybiera to, co było uważane za grzeszne, niemocne i słabe (por. 1 Kor 1,27). Zob. Katechizm Kościoła katolickiego, 121.

32 Określenie Zielińskiego (Literatura starożytnej Grecji, 122). 
a wszystko to dokonało się dzięki modlitwie, niezłomnej postawie i wierze tych kobiet w pomoc Boga. Dla Greka i Rzymianina byłyby one może szlachetne, gdyby nie dopuściły się czegoś odrażającego - tu popełniły po prostu nefas. W przypadku Judyty był to popis mistrzostwa ${ }^{33}$ : bezwstydnie schlebiała (Jdt 11,7-8), bezczelnie kłamała (Jdt 11,12-14.18-19), bezlitośnie zabijała (Jdt 13,7-8), hołdując zasadzie, że „W miłości i na wojnie wszystko wolno” i że „cel uświęca środki” ${ }^{34}$. W kulturze greckiej ideałem zdaje się być coś innego, podobnie jak u Pindara, modlącego się, by jego słowo „nigdy nie potknęło się o szorstkie kłamstwo"35, czy u Platona, propagującego ideę dobra, które oświeca i ożywia świat ${ }^{36}$. Ale w przypadku Judyty oszustwo i morderstwo dokonane z zimną krwią na bezbronnym wrogu, jako środki prowadzące do upragnionego celu, nie były dla Izraelitów wcale negatywne, przeciwnie - były uzasadnione, co więcej, bohaterka przez swój czyn zyskała w Izraelu cześć i szacunek.

Tym samym zresztą mogła się cieszyć Estera. Wygrała ona swoisty konkurs piękności (Est 2,8-9) i zajęła miejsce oddalonej żony władcy Persów, stając się królową światowego imperium (Est 2,17) - wielka kariera od sieroty do monarchini. Jednak biblijny autor ani żaden $\mathrm{z}$ bohaterów jego opowieści nie zwrócił uwagi na fakt, że związek Estery z poganinem Kserksesem był w istocie cudzołóstwem. Tak przynajmniej twierdziliby Grecy i Rzymianie ${ }^{37}$, powiedzieliby oni, że ów mariaż stanowił konkubinat czy też formę jawnej bigamii ${ }^{38}$ i że taki sposób życia z kobietą jest niegodziwy ${ }^{39}$.

Nie mamy tu zamiaru charakteryzować wszystkich starotestamentowych niewiast w kontekście grecko-rzymskiej obyczajowości ${ }^{40}$, chciałbym tylko zwrócić uwagę na różnicę, jaką dostrzegliby zapewne od razu Grecy i Rzymianie, porównując kobiety Starego Testamentu z Maryją. Poznając osobowość i biografię tak wspaniałej osoby, nie zachwyciliby się zapewne tamtymi żydowskimi bohaterkami. Obstawaliby oni przy twierdzeniu, że nie żyły one moralnie. Wspólną ich cechą negatywną i zarazem

33 Charakterystykę Judyty zob. w: Bosak, Leksykon wszystkich postaci biblijnych, 912-915.

34 Dziś postępowanie Judyty bywa inaczej interpretowane. O tej postaci w kontekście dzisiejszych czasów zob. Ryś, Błogosławiona między niewiastami.

35 Pindarus, Fr. 205 (Pindari carmina, 203). Zob. Komornicka, Studia nad Pindarem.

36 Zob. Podbielski, „Platon”, 597-611.

37 Już u Homera cudzołóstwo ma wymiar czynu etycznie nagannego. Kobieta zdradą hańbi swego małżonka (Odyssea 8, 285-286 [Siemieński, 104]), mąż niewiernością hańbi swą żonę (Iliados 9, 450-454 [Dmochowski, 118]). Związek boga wojny Aresa z Afrodytą, poślubioną Hefajstosowi, określony został mianem „cudzołóstwa” (Odyssea 8, 309 [Siemieński, 105]).

38 O problematyce małżeństwa i cudzołóstwa u Greków i Rzymian zob.: Reinsberg, Obyczaje seksualne, 22-25; Grimal, Miłość w Rzymie, 56-73.

39 O wysokiej wartości czystości małżeńskiej u Greków świadczą już poematy Homera. Np. ojciec Odyseusza, Laertes, rezygnuje z miłości do kupionej przezeń młodej i pięknej służącej Euryklei, by nie urazić uczuć swej małżonki (Odyssea 1, 450-457 [Siemieński, 23]).

40 Warto odnotować pozytywne przykłady kobiet izraelskich - typów Maryi - takich jak opisana w Księdze Sędziów Debora, prorokini i kobieta, sędzia, odgrywająca ważną rolę w społeczeństwie. Na dodatnią ocenę, zdaniem Greków i Rzymnian, zasługiwałaby zapewne także matka synów machabejskich z niemal stoickim podejściem do cierpienia swego i swych dzieci. 
prowadzącą do innych nikczemności, był wybujały erotyzm. Na scenie owej zmysłowości uwidaczniała się - na zasadzie kontrastu - doskonałość Maryi - idealnej Żony i Matki - Jej dobroć, czystość, wierność, całkowity brak jakichkolwiek gorszących ekscesów. Doskonałość tę, najogólniej rzecz biorąc, można by określić słowami Jana Pawła II mianem geniuszu kobiecego. Publiczność antyczna znała ten geniusz wcale nie najgorzej, bowiem w teatrach i w literaturze śledziła jego przejawy w postaciach szlachetnych bogiń, heroin i niewiast. Zaakceptowanie Maryi, przyjęcie jej wraz z całą jej nieskazitelnością nie stanowiło dla tych ludzi problemu, gdyż Matka Chrystusa wyrażała wszystkie obserwowane u nich i uznawane kobiece ideały.

\section{Maryja - Matka Boga}

Nie należy jednak sądzić, że jedynie etyczna doskonałość Maryi i znikomość innych kobiecych wzorców w kulturze Izraela ułatwiały rozpowszechnianie się kultu Przenajświętszej Dziewicy wśród pierwszych chrześcijan rekrutujących się z Greków i Rzymian. Były i inne powody, bardziej religijne, sakralnie i psychologicznie bardziej złożone. Z drugiej strony były też zdarzenia wręcz mitologiczne, które stanowiąc pewne niesamowite historie i legendy, paradoksalnie ułatwiały wyjaśnienie prawd wiary i dogmatów, choćby takich jak cud Wcielenia. Ogromną rolę odegrała tu również Ekloga IV Wergiliusza, utwór pod wieloma względami enigmatyczny ${ }^{41}$, niosący przesłanie streszczające się w słowach: Iam redit et Virgo, sugerujący, że zbawienie ludzkości zależy od Matki Zbawiciela, która jest Dziewicą. Działanie tych zjawisk było dwojakiego rodzaju: propagując niepokalaną Niewiastę, jednocześnie wyjaśniały jej macierzyństwo, czyniąc z niego fakt mający swe precedensy. Te dwa pojęcia - dziewictwo i macierzyństwo - w kulturze grecko-rzymskiej nie wykluczały się bowiem nawzajem, miały swe egzemplifikacje, czyli właśnie zdarzały się, niekoniecznie tylko w świecie mitów.

Temat ten rozwiniemy w dalszej części artykułu, na razie jednak przypomnijmy jedną z najważniejszych prawd wiary, określoną w Credo nicejsko-konstantynopolitańskim. Jest to wyznanie dotyczące Chrystusa, który „dla nas ludzi i dla naszego zbawienia zstąpił z nieba. I za sprawą Ducha Świętego przyjął ciało z Maryi Dziewicy". Słowa te, jak wiadomo, są niepojęte $\mathrm{z}$ tego powodu, iż zawierają stwierdzenie o poczęciu Dziecka z Ducha Świętego, a więc bez udziału mężczyzny; są niepojęte również dlatego, że mówią o narodzeniu poczętego Niemowlęcia z Dziewicy. Wydawałoby się, że trzeźwo myślący Grecy i Rzymianie mieliby trudności z przyjęciem tych prawd. W istocie jednak sprawa mogła przedstawiać się zupełnie inaczej.

Zob. Cytowska - Szelest, Literatura rzymska, 74-79. 
Propozycje mitologiczne, tak jak ajtiologicznie przedstawiały się one starożytnym, szły bardzo daleko. Począć nowe życie w sposób nietradycyjny, począć bez aktu płciowego, począć dziecko bez udziału mężczyzny, począć je, urodzić i zachować dziewictwo - to przecież znaczyło po prostu począć w sposób cudowny. W dodatku starożytni mieli rewelacyjne przesłanie wyjątkowości: nowe życie, jakie w ten sposób zaistniało, cechowało się zawsze niezwykłością, wyrastało ponad przeciętność, posiadało nadzwyczajne właściwości. Relacje o tych zjawiskach, wykraczających poza naturę, przybierały formy literackie, opracowywane z upodobaniem przez poetów i prozaików. Oto klacze, które stały się brzemienne, bo zadziałał na nie podmuch wiatru $^{42}$. Oto bogini Junona, którą zapłodniło dotknięcie kwiatu ${ }^{43}$. Oto Danae, która zaszła w ciążę w ten sposób, że zstąpił na nią Dzeus pod postacią złotego deszczu ${ }^{44}$. $\mathrm{W}$ przyrodzie, a więc $\mathrm{w}$ świecie realnym, cudowne poczęcie reprezentowała nieznająca męża Demeter, rodząca każdego roku trawy oraz zioła i zachowująca dziewictwo.

Nie należy oczywiście utożsamiać tych historii z chrześcijańską prawdą o Wcieleniu Bożego Syna, ale lekceważyć ich też całkiem nie można. Popularność takich opowieści o cudownych poczęciach daje jednak podstawę dla przypuszczenia, że mogły one stanowić analogię ułatwiającą rozumienie niesamowitych faktów dokonujących się podczas zwiastowania Maryi - coś, co działo się w świecie mitów i w przyrodzie, pomogło przybliżyć wyjaśnienie tajemnicy Wcielenia, a w efekcie - przyjęcie jej.

To są oczywiście propozycje mitologii nie o znaczeniu teologicznym, lecz raczej psychologicznym i kulturowym. Konkretne jednak jej sugestie i opowieści mogły rzeczywiście, poprzez różnego rodzaju analogie i paralele, torować drogę do uznania i przyjęcia prawdy o historii zbawienia. Dotyczyły nie tylko kwestii przyjęcia ludzkiego ciała i ludzkiej natury przez Drugą Osobę Trójcy Świętej, lecz właśnie okoliczności Zwiastowania, tła tego zdarzenia i jego bezpośredniego inicjatora, wykonawcy Bożych poleceń, istoty wręcz transcendentnej, zastępującej samego Jahwe, choć posiadającej cechy antropomorficzne. Publiczność antyczna miała zapewne do owego anioła Gabriela stosunek całkowicie aprobatywny, mógł się on jej kojarzyć z Hermesem, który to starożytny bóg pełnił - jak wiadomo - rolę posłańca ${ }^{45}$. Już u Homera zaświadcza o tym Odyseusz, gdy mówi: „Nagle mi drogę zachodzi Hermes z berłem

42 Homerus, Iliados 16, 148-150; 20, 221-222 (Dmochowski, 206, 260); Hesiod, Theogonia 378, 869 (Łanowski, 34, 76); Herodot 7, 189 (Herodotus, II, 54); Ovidius, Metamorphoses 6, 685-690 (BSGRT, 124); Ovidius, Tristia 3, 10, 45 (BSGRT, 72); Vergilius, Aeneis 3, 241 (Janell, 39).

43 Ovidius, Fasti 5, 20-25 (LCL 253, 265); Varro, De lingua Latina 5, 74; 7, 45 (M. Terentius Varro, De lingua Latina X, 85); Varro, De re rustica 1, 1, 6 (LCL 283, 38); Plinius, Historia naturalis 18, 29, 284 (Mayhoff, III, 131).

44 Hyginus, Fabulae 63 (Hygini fabulae, 152); Apollodoros 2, 4, 1 (Apollodor, Biblioteka opowieści mitycznych, 143); Horace, Ode 3, 16, 1 (Horacy, Dzieła, I, 185).

45 W sztuce starochrześcijańskiej posąg Hermesa niosącego cielca stał się wzorem wyobrażeń Chrystusa - Dobrego (młodego i pięknego) Pasterza, niosącego na swych barkach owcę. Zob. też rysunek na okładce Katechizmu Kościoła katolickiego, stanowiący fragment chrześcijańskiej płyty nagrobnej z końca III w., przedstawiający Chrystusa Dobrego Pasterza. 
złocistym... ten mi podaje prawicę i takim słowem przemawia..." (Od. 10, 274). Ale u Platona, w dialogu Uczta, gdzie pojawia się kapłanka Diotima z Mantynei, ucząca Sokratesa metafizycznych poglądów na miłość, mowa jest o istocie określanej mianem "demona” (daimon), przypominającej również aniołów Bożych, o których mówi Biblia. U greckiego filozofa na pytanie, czym jest ów demon, pada taka sławna odpowiedź: „On jest tłumaczem pomiędzy bogami a ludźmi, on od ludzi bogom ofiary i modlitwy zanosi, a od bogów przynosi ludziom rozkazy i łaski..."46. Postać anioła Gabriela, zjawiającego się przed Maryją i oznajmującego jej Boże plany, nie różniła się zatem zasadniczo od helleńskich wyobrażeń o boskich posłańcach i pośrednikach.

Analogii tych nie sposób lekceważyć, toteż zapewne dostrzegliby je ci Grecy i Rzymianie, którzy uważali, że zwykła śmiertelna kobieta może zostać matką bóstwa i zyskać w przyszłości cześć i chwałę. Jako przykład można podać Alkmenę, Semelę i Europę, rodzicielki istot boskich, to znaczy poczętych z inspiracji największego z bogów. Historie te były ogólnie znane, zresztą opisywane przez wielu autorów.

Odnaleźć można w tych opowieściach dużo paralel nie tylko do Maryi, ale także do samego Chrystusa. Heros (np. Herakles, Dionizos), który przychodził na świat ze związku boga z kobietą, był synem bożym (cara deum suboles, magnum Iovis incrementum), stawał się zbawicielem ludzkości. Czyny takiego bohatera, który potrafił pomagać najzwyklejszemu, „szaremu” człowiekowi, posiadały charakter uniwersalistyczny. Chodziło o to, że działał on nie tylko na obszarze swojej ojczyzny, ale przekraczał granice, niósł swoje orędzie i wsparcie przedstawicielom innych narodów oraz całemu światu. Właśnie takiego bohatera i odnowiciela zapowiadał także wspomniany już Wergiliusz w Eklodze IV. Helleński i rzymski zbawiciel ludzkości posiadał zatem wiele cech Chrystusa, matka owego zbawiciela przypominała zaś Maryję.

\section{Maryja - Dziewica}

Niezależnie od gloryfikacji macierzyństwa dokonywanej w mitologii i poezji, antyk grecko-rzymski doceniał także wartość dziewictwa ${ }^{47}$, przypominającą znaczenie, jakie chrześcijaństwo nadawało temu fizjologicznemu stanowi kobiety. To prawda, starożytność uprawiała również rozpustę i praktyki homoseksualne, wobec czego niektórzy autorzy, a nawet politycy odczuwali potrzebę piętnowania i nakłaniania ludzi do powrotu na drogę moralności ${ }^{48}$. Dziewictwo jednak było rzeczą upragnio-

\footnotetext{
46 Plato, Symposium 202e (Platon, Dialogi, 89).

47 Inaczej niż w tradycji Starego Testamentu, który nie przypisywał dziewictwu wartości, gdyż bezpotomna śmierć była hańbą dla Żydówek (Sdz 11,37). Zob. Leon-Dufour, Słownik teologii biblijnej, 452.

48 Por. wypowiedź Platona: „Ale żeby mężczyzna z mężczyzną, albo kobieta z kobietą? To jest przeciwko naturze" (Leges 636b [Platon, Państwo, Prawa, 245]). Cesarz Oktawian w swoim programie przeciwstawiał
} 
ną przez każdego, „zwykłego” mężczyznę, który szukał dobrej żony, spełniającej nie tylko cele prokreacji, lecz także będącej po prostu pomocniczką w życiowych sprawach $^{49}$. Starożytni cenili dziewictwo, nauczyli się tego od bogiń: Atena i Hestia to właśnie dziewice, które rządziły ważnymi dziedzinami społeczeństwa i państwa. Artemida to również dziewica, która identyfikowała się z przyrodą i cechowała niezwykłą urodą.

Połączyć dziewictwo z młodością, to znaczyło powiązać piękno z wielką miłością. Dlatego właśnie publiczność antyczna uwielbiała powieści, zwane też dzisiaj romansami ${ }^{50}$. Wymagała tylko od ich autorów, by ukazując dzieje wielkiego uczucia, uczynili swe bohaterki nie tylko pięknymi i młodymi dziewczętami, ale także dziewicami. Na przykład Achilleus Tatios ${ }^{51}$ (II w. po Chr.) posłużył się tematem burzliwej miłości między chłopakiem a dziewczyną, bynajmniej nie tworząc opowieści pornograficznej. Wręcz przeciwnie, dziewictwo zachowane aż do zawarcia związku małżeńskiego i wierność narzeczeńska tytułowej Leukippe, były bardziej wymowne niż hieratyczne postawy dziewiczych bogiń, stając się jednocześnie ideałem i wzorem do naśladowania.

Wolno chyba zatem stwierdzić, że - być może - aprobatywny stosunek starożytnych do dziewictwa, ujawniający się w literaturze, religii, a nawet instytucjach państwa $^{52}$, zdecydował o zaakceptowaniu dziewictwa Maryi, czy może raczej nie blokował przyjęcia tej prawdy. Zauważyć jednak trzeba, iż w takim razie ów panieński stan Matki Chrystusa przekraczał wszelkie wyobrażenia starożytnych, którzy nie potrafili pojąć ${ }^{53}$, że pomimo zrodzenia Syna Bożego, okazał się czymś trwałym. Niezwykła to zaiste okoliczność dla nich, że Maryja była „ZAWSZE Dziewicą" ${ }^{\text {. }}$. A przecież przechodzący na chrześcijaństwo Grecy i Rzymianie zaakceptowali i tę prawdę, przyjmowali dziewiczą Matkę Chrystusa jako swoją Matkę.

się rozwodom i proponował wartości rodzinne. Stoik rzymski Gajusz Musonius Rufus uważał stosunki homoseksualne za haniebne (Fr. 12 [C. Musonii Rufi reliquiae, 19]). Marek Aureliusz z kolei stwierdza, że cesarz Hadrian przyczynił się do ograniczenia pedofilii i występnej miłości (Marcus Aurelius, Meditationes 1, 16 [Pawlak - Reiter, 47]).

Już Hezjod radził poślubienie dziewicy, którą można „nauczyć dobrych zasad” (Opera et dies 695-705 [Hezjod, Narodziny Bogów,98]). U Ksenofonta Isomachos cieszy się zaś, że bierze za żonę dziewicę, która „umie tkać, prząść wełnę i wyznaczać robotę służebnym” (Xenophon, Oeconomicus 7 [Tymura, 58]). Zob. Dworacki, „Romans grecki”, 296-322; Rohde, Der griechische Roman; Helm, Der antike Roman; Hägg, The Novel in Antiquity; Polaszek, Antyczny romans grecki; Fusillo, Naissance du Roman.

51 Zob. Achilleus Tatios, Opowieść o Leukippe i Klejtofoncie.

52 W Rzymie istniała instytucja Westalek (Virgines Vestales) w liczbie sześciu. Utrzymywały one dniem i nocą w świątyni Westy wieczny ogień, który symbolizował trwanie państwa rzymskiego.

53 Na temat tych kontrowersji zob. Iustinus, Dialogus cum Tryphone Iudaeo 99, 7 (Iustini Martyris Dialogus cum Tryphone, 189); Orygenes, Contra Celsum 1, 32, 69 (Chadwick, 26). 


\section{Maryja - Orędowniczka}

W dziejach kultu maryjnego uderza stosunkowo wczesne, bo datowane na koniec III lub początek IV w., powstanie modlitwy Pod Twoją obronę i innych strzelistych aktów wyrażających wiarę w pomoc Maryi ${ }^{55}$. O ile jest to ważne $\mathrm{z}$ punktu widzenia mariologii, bo cześć dla Matki Chrystusa w pełni rozwinęła się już w pierwszych stuleciach chrześcijaństwa, o tyle wydaje się świadczyć o pewnym przygotowaniu mentalnym i literackim ówczesnych wiernych, jeśli chodzi o wizerunek Przenajświętszej Dziewicy jako Wspomożycielki i Orędowniczki. Grecko-rzymski antyk operował bowiem wizją bóstw i istot nieziemskich pomagających człowiekowi w różnych dziedzinach życia. Pomijając takich bohaterów, jak Herakles czy Tezeusz, którzy wybrali trudną i niebezpieczną drogę świadczenia dobrodziejstw różnym ludziom, trzeba sobie uświadomić, że cały szereg greckich miast-państw przyjmował poszczególnych bogów za swoich opiekunów ${ }^{56}$. Na przykład Ateny obrały na swoją protektorkę boginię Atenę, wielbiły ją tradycyjnym świętem Panatenaje ${ }^{57}$, a poezja poświęcona patronce stolicy Attyki posiada cechy swego rodzaju nabożeństwa i przypomina szacunek, jakim chrześcijanie będą darzyli Matkę Chrystusa. Podobne zatem zjawisko adoracji bogini Ateny ${ }^{58}$, traktowanej tam jako opiekunka miasta, obserwować można u Solona, Herodota i Eurypidesa. Charakterystyczny motyw obrony przed złem, owo przekonanie o posiadaniu potężnej rzeczniczki wobec bogów, wizja jej wzniesionych i otwartych ponad miastem dłoni, modlitwa ufności ujęta w formułę poetycką, słowem wszystko to, co kilka wieków później będzie w antyfonach adresowanych do Matki Bożej tak żywe, że już powszechne, pojawia się u Solona w jego sławnej elegii o praworządności (Fr. 4, E):

Miasto nasze nigdy z woli Dzeusa nie zginie, ani z losu bogów szczęśliwych i nieśmiertelnych, albowiem Pallas Atena, wielkoduszna strażniczka, córa potężnego ojca wznosi nad nami swe dłonie ${ }^{59}$.

55 Na temat datacji tych modlitw zob. Starowieyski, „Tytuł Theotokos”, 421-423.

56 W centrum miasta-państwa, w budynku zwanym prytaneum, znajdowało się ognisko, poświęcone Hestii - opiekunce, płonął tu niegasnący ogień, symbolizujący świętość tego miejsca. Oprócz Hestii miasto-państwo czciło swego Dzeusa Miejskiego (Dzeus Polieus), któremu poświęcone było święto Dipolia i obrzęd bufonii.

57 Zob. Winniczuk, Twórczość poetek greckich, 547-549.

58 Atenę czczono nie tylko jako opiekunkę miasta. Palladzie poświęcona była również praca rzemieślnicza, sztuka tkacka oraz garncarstwo. Zachowały się do naszych czasów modlitwy Ateńczyków kierowane do bogini, świadczące, że te rzemiosła były jej domeną. Zob. Zieleński, Religia starożytnej Grecji, 57-58.

59 Zob. Komornicka, Poezja starożytnej Grecji, 78. Zob. też o Pytii: Herodot 7, 141 (Herodotus, II, 231). Zob. też Euripides, Ion 1616 (Łanowski, 191), u którego Atena zstępując z Olimpu, towarzyszy królowej Kreuzie w drodze do Aten i pociesza ją słowami: „Kr. Idźmy już do domu, synu! - At.: Idźcie; z wami pójdę ja. Kr.: Zacna towarzyszko nasza! - At.: Tak, i miłująca gród”. 
Nie tylko zatem chrześcijanie mieli potężną Orędowniczkę, ale już wcześniej starożytni Ateńczycy ${ }^{60}$ byli przekonani, że taką posiadają. Prezentowane wyżej wersy to ciekawe połączenie wątków nadprzyrodzonych i religijnych. Można chyba założyć, że starochrześcijańskie modlitwy wyrażające wiarę w pomoc Maryi właśnie z tej strony otrzymały sukurs i zastrzyk motywów, w dalszym ciągu aspirując do miana utworów oryginalnych. Bo przecież dla człowieka ochrzczonego w wierze Chrystusa możliwość powrotu do pogańskich formuł absolutnie już nie wchodziła w grę: takie wiersze nie nadawały się do liturgii. Co wcale nie wyklucza, że chrześcijanie, jeśli potraktowali bałwochwalcze teksty nie tylko pogardliwie, lecz również aktywnie i twórczo, mogli adoptować i chrystianizować poszczególne motywy związane ze światem greckich i rzymskich bogów. Nieadekwatność kultu dwóch religii nie przerwała swoistej więzi między nimi, o której mogą świadczyć również modlitwy wyrażające wiarę w pomoc Maryi, nasycone - w pewnym stopniu - reminiscencjami i similiami przedchrześcijańskiej kultury i literatury antycznej.

\section{Maryja - Madonna z Dzieciątkiem. Ujęcia plastyczne}

Inna rzecz, że ze strony tej grecko-rzymskiej kultury, propagującej kobiece ideały, które w pełni zrealizowały się w osobie Maryi, także sztuka chrześcijańska ukazująca wizerunki Przenajświętszej Dziewicy z Dzieciątkiem ${ }^{61}$ otrzymała specyficzne wsparcie. Można bowiem traktować popularne także i dziś ikonograficzne wyobrażenia Matki Bożej przytulającej małego Jezusa jako chrześcijańską reakcję na stare, funkcjonujące w rzeźbie antycznej portrety bogini - matki z boskim dziecięciem. Tadeusz Zieliński ubolewał ${ }^{62}$, że greccy i rzymscy artyści rzadko posługiwali się tym wdzięcznym motywem, choć obecny był on w religii antycznej. Demeter z Iakchosem, Rea z Dzeusam, Afrodyta z Erosem - to były gotowe projekty ujęć plastycznych. Rzeźba antyczna (celowo pomijamy tu malarstwo ze względu na nietrwałość tej dziedziny sztuki i - w związku z tym - niewielką liczbą zachowanych do naszych czasów artefaktów, wśród których brak jest wizerunków ukazujących matkę z niemowlęciem na ręku) nie wyciągnęła jednak jakichś dalej idących wniosków z tych propozycji. Zachowane do naszych czasów wyobrażenia są nieliczne, niemniej posiadają te najistotniejsze cechy, które później urzeczywistnią się w owej intymnej idei religijnej motywu Madonny z Dzieciątkiem. Wyrażały one bowiem koncepcję macierzyństwa,

60 Nie tylko Atena pełniła taką rolę. Lud ateński zanosił modły także do Afrodyty, zwłaszcza w sprawach sercowych. Por. sławna modlitwa Safony: „Przybądź tutaj, jak nieraz bywało na głos prośby mojej z dala nadchodzącej i wysłuchaj - ojca pałac opuściwszy w złotym rydwanie” (Komornicka, Poezja starożytnej Grecji, 67). Zapewne i taką modlitwę Matka Boża by dziś przyjęła.

61 Ogólnie o wyobrażeniach Maryi w kulturze europejskiej zob.: Pelikan, Mary Through the Centuries.

62 Zieliński, Religia hellenizmu, 240. 
przedstawiały młodą mamę, przedstawiały niemowlę na jej ręku, tworząc swego rodzaju konwencję, i podkreślały szczególną więź łączącą dziecko z jego rodzicielką.

Jedno z najstarszych tego typu wyobrażeń należy do sztuki egipskiej. Jest to brązowa figurka Izydy z Horusem, pochodząca z czasów XVIII dynastii (ok. 1360 r. przed Chr.), znajdująca się obecnie w Muzeum Narodowym w Warszawie. Plastyczne ujęcie, które sprawia wrażenie pewnej sztuczności, afiszuje się dostojeństwem bijącym z postawy bogini siedzącej sztywno i dość obojętnie, karmiącej beznamiętnie lewą piersią Horusa, zyskuje jednak przez to szczególną sytuację, wyjątkowy walor łącz-

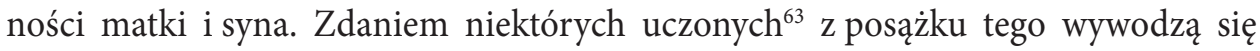
późniejsze, chrześcijańskie wyobrażenia Madonny z Dzieciątkiem. Wizerunek Izydy z Horusem, przypominający z grubsza rzeczywiście portrety Maryi i Jezusa, może jednak zwieść, brak jest bowiem jakichkolwiek dowodów na poparcie tezy, o takim twórczym impulsie. Zastosowany motyw bogini z boskim synem ${ }^{64}$ daje się $\mathrm{w}$ istocie porównać z konterfektami Madonny z Dziecięciem, wygląda ciekawie, choć oschle, jednak mogło to być tylko przypadkowe podobieństwo, nie zaś jakaś bezpośrednia inspiracja, choć i tej nie należy wykluczać.

Sztuka chrześcijańska mogła więc pozyskiwać impulsy twórcze z tradycji egipskich, lecz przede wszystkim czerpała je z własnych idei, z własnej wiary oraz z Biblii. Zastając antyczne artefakty jako gotowe tematy, jako coś artystycznie dopracowanego, jako mitologię niewymagającą traktowania zbyt serio, ocaliła te dzieła, dostosowała je do własnych potrzeb i dała im nowe życie. W ten sposób zapewne potraktowano owo wyobrażenie Izydy z Horusem, przekształcono je świadomie w kierunku teologicznej umowności i oto wizerunek, przestając naśladować scenę mitologiczną, zyskał zupełnie nową wymowę, stał się chrześcijański, stał się tożsamy z przekazem Ewangelii, w której pojawia się motyw „Dziecięcia z Matką Jego, Maryją" (por. Mt 2,11).

Sztuka chrześcijańska, wykorzystując fakt, że dziedzictwo grecko-rzymskie odnosiło się do szeregu problemów ogólnoludzkich i ogólnokulturowych, wprzęgło je do swego rydwanu teologii i idei poprzez używanie jego środków artystycznych oraz przez wykorzystywanie jego motywów w niezliczonych transkrypcjach i przeróbkach. Nie kopiowano bezkrytycznie, nie sięgano do sztuki pogańskiej wprost, bez przetworzeń i obsłonek. Artyści chrześcijańscy robili z tematów i technik antycznych własne oryginalne arcydzieła, a gorliwość wiernych postawiła w świetle świec i pochodni wizerunki Madonny z Dzieciątkiem. Wyobrażenia te zyskały rzeszę czcicieli i olbrzymią popularność, lecz jednocześnie świadczyły o zjawisku, o którym tu ciągle napomykamy: pojawiły się, bo takie były potrzeby i oczekiwania nawróconych, ujawniło się przygotowanie tych ludzi - uprzednio pogan - do odbioru tematu boskie-

\footnotetext{
63 Carrol, The Cult of the Virgin Mary, 111; Vassilaki, Images of the Mother of God, 4.

64 Podobny motyw pojawia się w rzeźbie Ejrene z małym Plutosem dłuta Kefisodota (IV w. przed Chr.). Stojąca bogini wpatruje się w siedzącego na jej lewej ręce chłopca, dzierżącego róg obfitości.
} 
go macierzyństwa i dziecięctwa. Tradycja istniejąca w ekstrakcie mitologicznym nie przestała się liczyć, ona zorganizowała grunt, przyszykowała bazę dla chrześcijańskich artefaktów. Masowe uznanie portretów Maryi z Jezusem było pokwitowaniem ważności tego pogańskiego dziedzictwa.

\section{Maryja - Matka Bolesna}

Nasuwają się jednak pytania: Czy antyk grecko-rzymski znał tylko obrazy szczęśliwego macierzyństwa? Czy był przygotowany na przyjęcie prawdy o cierpieniu Matki Bożej, tracącej swe jedyne Dziecko, której duszę miecz przeniknął, „aby na jaw wyszły zamysły serc wielu" (Łk 2,35)? Poganie przyjmujący chrześcijaństwo mogli do sprawy udręki matki odnosić się ze zrozumieniem, powołując się na przykład bogini Demeter i jej córki Persefony.

Mogli więc wskazywać, że niebianka straciła swą jedynaczkę, którą porwał Hades w czeluści Tartaru, i że z tego powodu doświadczyła wielkich męczarni. Cała ta historia, także legenda o Niobe, zapewne miały znaczenie dla adeptów nowej wiary: mitologia, a z nią literatura i sztuka, dostarczały ilustracji matczynego bólu, zaznajamiały z tematem, który stanie się ważną częścią pasji Chrystusa. I tu równocześnie rysowała się istotna różnica między cierpiącą Maryją a Demeter czy Niobe, owładniętymi przez skrajną rozpacz. Matka Chrystusa cechowała się niezwykłym opanowaniem, wynikającym z bezgranicznego zaufania Bogu. Według ewangelisty ani nie płakała, ani nie słaniała się ${ }^{65}$, ona po prostu stała pod krzyżem (por. J 19,25) ${ }^{66}$. Dostrzegli to zapewne Grecy i Rzymianie, zafascynowani taką postawą. Nie mamy oczywiście jakichś bezpośrednich dowodów na poparcie tej tezy. Możemy jednak domniemywać, że w istocie tak było, że Maryja poprzez swoje cierpienie i zawierzenie stała się szczególnie bliska dla tych ludzi.

\section{Wywyższenie Maryi}

Starochrześcijańska cześć dla Matki Chrystusa jest jednak faktem, lecz masowość tego zjawiska nie likwidowała skomplikowania pewnych problemów teologicznych. Sytuacja Przenajświętszej Dziewicy, jej wywyższenia, określonego miejsca w planie

65 Inaczej tę sytuację widzieli późniejsi artyści, którzy tworzyli dzieła z gatunku „planctus”, ukazujące lamentującą Maryję. Przykładem takiego utworu w literaturze polskiej jest Lament świętokrzyski (zwany też jako Żale Matki Boskiej pod krzyżem).

66 „Stanie” Maryi pod krzyżem, nieokazywanie przez Nią negatywnych uczuć, miało wiele wspólnego z postawą stoicką, choć oczywiście motywacja takiego zachowania była zupełnie inna. 
zbawienia, szczególnej pozycji wobec Boga i w dziejach ludzkości ${ }^{67}$ była (i jest) trudna do pojęcia. Wprawdzie wiadomo, że Maryja dostąpiła wyjątkowego uprzywilejowania i pełni łaski, ale tajemnic tych nikt jeszcze do końca nie wyjaśnił. Również poganie przechodzący na chrześcijaństwo stawiali sobie zapewne zapytania w wielu kwestiach mariologicznych. Szukając na nie odpowiedzi, odwoływali się do własnych doświadczeń, klimatu kulturowego, motywów religijnych i literackich i znajdowali tu pewną pomoc w przybliżaniu się do rozumienia prawd nowej wiary.

Mogli odnieść się do postaci Ateny, jak już mówiliśmy, opiekunki miasta, lecz w przypadku tej figury zdumiewało także jej pochodzenie, urodzenie się z głowy Dzeusa, świadczące o wyjątkowości bogini stanowiącej myśl, rozum, mądrość, tj. logos najwyższego z bogów. Cała ta propozycja była w jakiś sposób współrzędna i użyteczna w tworzeniu analogii, bo pogańska niebianka i Maryja posiadały wspólną cechę, obie łączyła z Najwyższą Istotą jakaś szczególna więź. Potwierdzenie tej okoliczności pierwsi chrześcijanie mogli znajdować również u poetów, którzy Palladę określali mianem $\pi \dot{\alpha} \rho \varepsilon \delta \rho o \varsigma$ Dzeusa, tzn. posiadającą tron tuż obok tronu ojca bogów ${ }^{68}$. Paralela między Maryją wziętą do Nieba ${ }^{69}$ a Ateną znowu stawała się tu bardzo wyraźna, zwłaszcza że grecka bogini zstępowała z niebios, by wspierać zawsze bohaterów pełniących wolę Dzeusa, takich jak np. Perseusz, Jazon, Herakles czy Odyseusz $^{70}$. Podobnie zresztą czyni i Maryja wobec wszystkich ludzi, którzy oddają się pod jej opiekę.

Zatem przyjmujący chrześcijaństwo Grecy i Rzymianie, porównując obie niewiasty, zauważali zapewne te zgodności, to zresztą był ich atut, że w swojej kulturze posiadali odpowiednik Maryi. Mieli więc z jednej strony mityczną boginię, która imponowała mądrością i męstwem, z drugiej zaś strony osobę jeszcze doskonalszą, lecz całkiem realną, zupełnie zwyczajną, choć równocześnie ponad wszystko przez Boga wywyższoną. Historia pokazała, że ci, którzy przyjmowali chrześcijaństwo, nie byli rozdarci ani niezdecydowani, woleli Maryję. Była to postawa mająca urok wiary i pod pewnym względem twórcza, bo przeniknięta fermentem helleńskiej cywilizacji.

Wydaje się jednak, że ze wszystkich religii obowiązujących w państwie rzymskim, największą rolę w przygotowaniu ludzi na przyjęcie Maryi jako istoty wywyższonej przez Boga, odegrały religie wschodnie. Wynikało to z faktu, że takie wierzenia, jak wierzenia związane z Wielką Macierzą Bogów - Kybele czy Izydą, cieszyły się niezmierną popularnością, stając się oficjalnymi religiami w państwach hellenistycznych, by następnie przenieść się do Grecji i Rzymu. Kybele i Izyda były

\footnotetext{
67 Zob. Jan Paweł II, Redemptoris Mater. O wyjątkowości powołania i przeznaczenia Maryi zob. też: Życiński, Matka, która pozostała dziewicą.

68 Horacy, Ode 1, 12, 17 (Horacy, Dzieła, I, 57). Motyw „paredros” pojawia się także w Biblii i odnosi się do Mądrości, która dzieli tron z Bogiem. Zob. Mdr 9,4.

69 Dogmat ten ogłoszono dopiero w 1950 r., niemniej wiara w wniebowzięcie Maryi była obecna w Kościele od pierwszych wieków chrześcijaństwa.

70 Zob. Zieliński, Hellenizm a judaizm, 68-69.
} 
boginiami o charakterze przede wszystkim mistycznym i ekstatycznym, obiecywały swoim wyznawcom nieśmiertelność i życie pozagrobowe w wiecznej szczęśliwości. Oczywiście nie miały nic wspólnego ani z Chrystusem, ani z Maryją, ale pretendentowi do wiary chrześcijańskiej mogły kojarzyć się z Matką Bożą, zwłaszcza że boską mocą przywróciły do życia swych ulubieńców - Attisa i Ozyrysa. Tak właśnie ową asocjację między pogańskimi boginiami a Maryją widział zapewne św. Grzegorz Cudotwórca (ok. 213-273) z Kapadocji, który prawdopodobnie zdając sobie sprawę z potęgi dawnych kultów, zezwolił swym wiernym na oddawanie czci Matce Bożej, choć niektórzy chrześcijanie - ci bardziej fanatyczni, widzieli w tym przejaw bałwochwalstwa ${ }^{71}$.

W istocie zwycięstwo kultu maryjnego stało się ekwiwalentem wierzeń w pogańskie bóstwa żeńskie. Łączyło się to prawdopodobnie również z faktem, że o ile Kybele i Izyda były boginiami orgiastycznymi, czczonymi w misteriach tylko przez wtajemniczonych istotami niejednoznacznymi, bo identyfikowanymi z innymi bóstwami, zwierzętami, a nawet pojęciami (Demeter, Rea, Afrodyta, magia, metamorfoza, wąż, lew, itd.), o tyle Maryja posiadała ściśle określoną osobowość, jawiła się jako konkretna Kobieta z krwi i z ciała, odgrywająca przy tym wyrazistą rolę w dziele zbawienia zaplanowanym przez Boga, stająca się Matką Kościoła i każdego człowieka, a zatem osobą dostępną dla wszystkich ludzi - bez wyjątku; w dodatku istotą potężną, pokonującą wszelkie zło.

Wszystkie te okoliczności miały zapewne duże znaczenie dla adepta nowej wiary, dlatego że zarówno proponowały atrakcyjną pod każdym względem niewiastę czy indywidualność doskonałą, choć wrażliwą na potrzeby maluczkich, jak i odwoływały się w jakimś stopniu do tradycji dawnych pogańskich wierzeń. Równocześnie zaczęły dokonywać się - za sprawą Maryi - cuda. Świadkami maryjnej epifanii, poza wymienionym powyżej św. Grzegorzem Cudotwórcą, były np.: św. Tekla, dziewica Justyna i jacyś grzesznicy, których Maryja wzywała do nawrócenia ${ }^{72}$. Z tymi zdarzeniami liczył się każdy, kto chciał przyjąć wiarę w Chrystusa $^{73}$. Jeśli pominiemy cudowne zjawiska, to trzeba jednak nadal wskazywać na fakt, że Maryja dla tych ludzi pozostawała osobą fascynującą. Tu właśnie rysowała się ważna rola dawnych pogańskich kultów. Religie te miały niezwykle istotną rolę w rozbudzeniu eschatologicznych potrzeb ówczesnego człowieka, które w pełni mogły zostać zaspokojone tylko w Chrystusie i Jego Matce wywyższonej przez Boga.

Zieliński, Religia starożytnej Grecji, 89.

Starowieyski, „Najstarszy opis mariofanii”, 735-744.

Wipszycka, Kościół w świecie późnego antyku, 300-317. 


\section{Wnioski}

Postać Maryi i przesłanie wiary chrześcijańskiej w ogóle znalazły się w świecie antycznym w sytuacji pod pewnym względem uprzywilejowanej, stosunkowo szybko zostały zaakceptowane przez rzesze nowych wyznawców, rozprzestrzeniając się prędko po obszarach Imperium Romanum. $Z$ jednej strony ciążyły na rozwoju chrześcijaństwa krwawe prześladowania oraz różnego rodzaju represje, z drugiej strony pogańska kultura, choćby religia, filozofia czy literatura, wcale nie pozostawały bez znaczenia dla ekspansji nowej wiary, jako że nawróceni Grecy i Rzymianie mogli znaleźć w nauce tworzącego się Kościoła pewne nieobce im ideały, a takie zasady moralne, jak np. umiłowanie prawdy, lojalność, poszanowanie dziewictwa, miłość i czystość małżeńska, były w cywilizacji grecko-rzymskiej powszechnie znane i uznawane. W tej sytuacji, wraz z czcią oddawaną Chrystusowi, na odpowiednio przygotowanej bazie antycznych religii i wzorców cnót kobiecych, krzewił się kult Maryi z jej szczególnymi atrybutami. Takim atrybutem było jej Boże macierzyństwo, znajdujące paralele w starożytnej mitologii. Podobnie i dziewictwo Maryi nie stało w sprzeczności z tradycjami tamtejszej cywilizacji.

Stwierdzając swoiste przygotowanie świata antycznego na przyjęcie orędzia Maryi, warto się jednak zastanowić, czy nie brak w postawie samej Przenajświętszej Dziewicy jakiegoś doświadczenia helleńskiej kultury, a nawet znajomości jej najistotniejszych aspektów. Jeśli cywilizacja antyczna zaakceptowała Maryję, o czym świadczy cześć oddawana jej osobie już w pierwszych wiekach chrześcijaństwa, to może należałoby rozważyć, czy ona sama mogła ów pogański świat w jakiś sposób rozumieć. Rozumienie wszakże prowadzi często do aprobaty, do uznania pewnych pozytywnych wartości, które bez wątpienia tkwiły w grecko-rzymskiej kulturze. Oczywiście jakiekolwiek stwierdzenia w tym zakresie muszą być w większości przypadków, siłą rzeczy, hipotetyczne, gdyż bezpośrednie świadectwa historyczne dotyczące biografii Maryi są niezwykle skąpe, niemniej wielka jest tu rola ewangelistów prezentujących pewne istotne momenty jej życia, czyli właśnie dane dotyczące m.in. kwestii geograficznych i treści nielicznych wypowiedzi Matki Chrystusa.

Ojczyzna Maryi, gdzie spędziła większą część swego życia - Galilea, czyli „dzielnica pogan" (galil hag - gojim), otoczona była z trzech (a w zasadzie ze wszystkich czterech) stron przez świat helleński. Na północy znajdowała się Celesyria (gr. Koile Syria, łac. Coelesyria) z nadjordańskim miastem Paneadą, nawiązującym już samą swą nazwą do pogańskiego boga pasterzy. Na zachodzie rozciągała się kraina z portem Ptolemaidą (nazwanym tak w 261 r. przed Chr. na część Ptolemeusza II Filadelfosa) oraz Tyrem i Sydonem - metropoliami sławnymi ze szkół retorycznych. Na zachodzie leżała Dekapolis - konfederacja dziesięciu miast zamieszkanych głównie przez ludność grecką. Na południu z kolei Galilea sąsiadowała z „heretycką” Samarią, zawierającą w sobie helleński gród o tej samej nazwie. W samej zaś Galilei wznosiła się tajemnicza Scythopolis - helleńska metropolia. Z dużą dozą prawdopodobień- 
stwa możemy zatem domniemywać, że ojczyzna Maryi - w jej epoce - znajdowała się w kręgu przemożnego promieniowania kultury greckiej. Nie wiemy, na ile przekształcało ono życie mieszkańców tej krainy, niemniej faktem jest, że Galilejczycy nadawali swym dzieciom imiona greckie, jak Andrzej czy Filip (por. imiona apostołów), posiadali swoją własną, „kresową” odmianę języka (por. Mt 26,73), swój własny patriotyzm i styl bycia, bardzo nieraz różny od tradycyjnych wzorców judaizmu ${ }^{74}$. Według Talmudu więcej dbali o sławę niż o zysk ${ }^{75}$, w czym przypominali Greków, których Horacy określił mianem: praeter laudem nullius avari (Ars poetica 323 ${ }^{76}$. Nie sposób tu oczywiście formułować jakieś dalej idące wnioski, w każdym razie wydaje się raczej pewne, że Maryja, mieszkająca w Galilei przez kilka dekad, musiała spotykać się z przejawami kultury greckiej, wchodzić z nią w bezpośredni kontakt. Nie od rzeczy też będzie przypomnieć o jej pobycie w hellenistycznym Egipcie (Mt 2,13-19), gdzie mieszkała wraz ze swoją rodziną aż przez 3 lata po ucieczce z Ziemi Świętej przed okrutnym Herodem. Tu również niemal na każdym kroku stykała się z grecką cywilizacją i rzymską administracją ${ }^{77}$. Czy znała grekę, która w tej części świata była językiem powszechnie obowiązującym? Zapewne tak. Jako osoba na pewno bardzo inteligentna, wrażliwa, niezwykle spostrzegawcza (por. J 2,3), rozważająca sprawy w swoim sercu (por. Łk 2,19), musiała interesować się otaczającym ją światem, poznawać go, komunikować się z nim (choćby robiąc sprawunki, jak każda mama), wchodzić w relacje.

Trudno natomiast stwierdzić, czy miała doświadczenie greckiej literatury. Mamy bowiem jej jedną tylko dłuższą wypowiedź - w wersji Łukasza (Greka), sławny Magnificat (Łk 1,46-55), wysnuty, jak chcą bibliści, z ducha Psalmów, zainspirowany kantykiem Anny (1 Sm 2,1-10) ${ }^{78}$. Niemniej w tym tekście uderza czytelnika archaicznej poezji greckiej zwłaszcza sformułowanie mówiące o potędze Boga: „On przejawia moc ramienia swego, rozprasza [ludzi] pyszniących się zamysłami serc swoich. Strąca władców z tronu, a wywyższa pokornych. Głodnych nasyca dobrami, a bogatych z niczym odprawia" (Łk 1,51-53).

W słowach tych wyśledzić się daje podobieństwo ${ }^{79}$ do ustępu z hymnu ku czci Dzeusa - utworu napisanego przez żyjącego w VII w. przed Chr. Hezjoda (Prace i dni 3-8):

On sprawia, że ludzie śmiertelni są zapomniani lub głośni, na ustach wszystkich lub nikomu nieznani.

\footnotetext{
74 Koła żydowskie z południa pogardliwie patrzyły na Galilejczyków (por. J 7,41-42.52), którzy nie przestrzegali skrupulatnie Tory (J 7,41-42.54). Nie do pomyślenia było też, aby stąd mógł się wywodzić jakiś prorok (Łk 4,21-24; J 7,52).

75 Zob. Zieliński, Hellenizm a judaizm, 18.

76 Warto zwrócić uwagę na fakt, że nie był Galilejczykiem ten, który dla pieniędzy zdradził Chrystusa.

77 Egipt znalazł się pod rzymskim panowaniem w 31 r. przed Chr.

78 Na temat Magnificat zob.: Haręzga, „Magnificat”, 490-493.

79 Zauważyła je Anna Komornicka (Poezja starożytnej Grecji, 40-41).
} 
Bo tak się władcy Dzeusowi podoba.

Łatwo jednemu da siłę, łatwo obali mocnego,

łatwo dumnego ukorzy, a nieznacznego wywyższy,

łatwo naprostuje skrzywione, a pyszałka wyniszczy.

Dzeus gromowładny, który zasiada w podobłocznym pałacu ${ }^{80}$.

Oba teksty realizują podobny motyw, jakim jest Boża sprawiedliwość wynosząca maluczkich, a poniżająca pysznych. Oczywiście paralela między utworami może być zupełnie przypadkowa, wynikła np. z ogólnoludzkich, archetypicznych wyobrażeń Greków o istocie boskości ${ }^{81}$. Lecz jeśli nawet nie ma tutaj jakichś bezpośrednich oddziaływań i inspiracji, to istnieje jednak między tymi dziełami owa niewątpliwa analogia. Jest to właśnie analogia Bożego miłosierdzia i swoistej dwubiegunowości „uniżenia - wywyższenia”.

Były więc w postawie Maryi i jej słowach obecne elementy, które z pewnością intrygowały Greków i Rzymian, przyjmujących nową wiarę. Postać Matki Chrystusa określić by można jako ideał, ujmujący najbardziej wzniosłe i całkiem zwyczajne, antyczne, humanistyczne (i literackie) wzorce zachowań.

\section{Bibliografia}

Achilleus Tatios, Opowieść o Leukippe i Klejtofoncie (opr. R.K. Zawadzki) (Częstochowa: Wydawnictwo WSP 2002).

Apollodor, Biblioteka opowieści mitycznych (tł. T. Mojsik) (Biblioteka Antyczna 60; Wrocław: ISKŚiO UWr 2018).

Arystofanes, Komedie (tł. K. Ławińska-Tyszkowska) (Biblioteka Antyczna; Warszawa: Prószyński i S-ka 2001-2003) I-II.

Beinert, W. - Petri, H. (red.), Handbuch der Marienkunde (Regensburg: Pustet 1984).

Benko, S., The Virgin Goddess. Studies in the Pagan and Christian Roots of Mariology (Leiden Boston, MA: Brill 2004).

Bieżuńska-Małowist, I., Kobiety antyku, talenty, ambicje, namiętności (Warszawa: PWN 1993). Bosak, P.C., Leksykon wszystkich postaci biblijnych (Kraków: Petrus 2015).

Bracha, F., „Zarys historii mariologii polskiej”, Gratia plena. Studia teologiczne o Bogurodzicy (red. B. Przybylski) (Poznań: Wydawnictwo Polskiej Prowincji Dominikanów 1965) 457-486.

Brown, R.E. - Fitzmyer, J.A. - Murphy, R.E. (red.), Katolicki komentarz biblijny (Warszawa: Vocatio 2013).

Caius Musonius Rufus, C. Musonii Rufi reliquiae (red. O. Hense) (Whitefish, MT: Kessinger 2010). Carrol, M.P., The Cult of the Virgin Mary. Psychological Origins (Princeton, NJ: Princeton University Press 1986).

80 Zob. Komornicka, Poezja starożytnej Grecji, 40.

81 O ludzkiej, „naturalnej” tęsknocie za Bogiem zob.: Dupuis, Chrześcijaństwo i religie, 33-34. 
Cytowska, M. - Szelest, H., Literatura rzymska. Okres augustowski (Warszawa: PWN 1990).

Ćwik, K., „Kształtowanie się dogmatów chrystologicznych na soborach pierwszych wieków”, Collectanea Theologica 84/3 (2014) 31-47.

Denzinger, H. - Schönmetzer, A., Enchiridion symbolorum, definitionum et declarationum de rebus fidei et morum, wyd. 36 (Freiburg im Br.: Herder 1976) (= DS).

Dupuis, J., Chrześcijaństwo i religie. Od konfrontacji do dialogu (Kraków: WAM 2003).

Dworacki, S., „Romans grecki”, Literatura Grecji starożytnej. II. Proza historyczna, krasomówstwo, filozofia i nauka, literatura chrześcijańska (red. H. Podbielski) (Lublin: TN KUL 2005) 295-322.

Dzielska, M., „Kierunki badań nad historią religii greckiej i hellenizmu oraz nowsza literatura przedmiotu", T. Zieliński, Religia starożytnej Grecji (Wrocław: Ossolineum 1991) 277-296.

Esler, Ph.F., „The Mediterranean Context of Early Christianity”, The Early Christian World (red. Ph.F. Esler) (London: Routledge 2002) 3-26.

Euripides, Ion, tł. J. Łanowski: Eurypides, „Ijon”, Eurypides, Tragedie (Warszawa: Prószyński i S-ka 2007) II.

Fernández, D., „Aktualność i wartości mariologii Ojców Kościoła”, Częstochowskie Studia Teologiczne 11 (1983) 73-91.

Fusillo, M., Naissance du Roman (Paris: Éditions du Seuil 1991).

Gambero, L., Mary and the Fathers of the Church. The Blessed Virgin Mary in Patristic Thought (San Francisco, CA: Ignatius Press 1999).

Grimal, P., Miłość w Rzymie (tł. J.R. Kaczyński) (Warszawa: PIW 1990).

Hägg, T., The Novel in Antiquity (Oxford: Blackwell 1983).

Haręzga, S., „Magnificat”, Nowy słownik teologii biblijnej (red. H. Witczyk) (Lublin: TN KUL Kielce: Jedność 2017) 490-493.

Helm, R., Der antike Roman (Berlin: Wissenschaftliche Editionsgesellschaft 1948).

Hezjod, Narodziny Bogów (Theogonia), Prace i dni, Tarcza (tł. J. Łanowski) (Biblioteka Antyczna; Warszawa: Prószyń-ski i S-ka 1999).

Homerus, Iliados, tł. F.K. Dmochowski: Homer, Iliada (Biblioteka Klasyki polskiej i Obcej; Kraków: Wydawnictwo Literackie 1974).

Homerus, Odyssea, tł. L. Siemieński: Homer, Odyseja (Warszawa: Paprocki i S-ka 1895).

Horacy, Dzieła (tł. S. Gołębiowski) (Biblioteka Klasyki Polskiej i Obcej; Warszawa: Ludowa Spółdzielnia Wydawnicza 1980) I-II.

Hyginus, Hygini fabulae (red. P.K. Marshall) (Bibliotheca Scriptorum Graecorum et Romanorum Teubneriana; Berlin: De Gruyter 2002).

Iustinus, Iustini Martyris Dialogus cum Tryphone (red. M. Marcovich) (Berlin: De Gruyter 1997).

Jan Paweł II, „Encyklika Redemptoris Mater”, Encykliki Ojca Świętego Jana Pawła II (Kraków: Wydawnictwo M 1996) I, 259-317.

Jeffers, J.S., The Greco-Roman World of the New Testament Era. Exploring the Background of Early Christianity (Downers Grove, IL: IVP Academic 1999).

Johnson, L.T., Among the Gentiles. Greco-Roman Religion and Christianity (New Haven, CT: Yale University Press 2009).

Jurewicz, O. - Winniczuk, L., Starożytni Grecy i Rzymianie w życiu prywatnym i państwowym (Warszawa: PWN 1973).

Katechizm Kościoła katolickiego (Poznań: Pallottinum 1994). 
Komornicka, A.M., Poezja starożytnej Grecji. Wybrane gatunki literackie (Łódź: Wydawnictwo UŁ 1987).

Komornicka, A.M., Studia nad Pindarem i archaiczną liryka grecką. W kręgu pojęć prawdy i fatszu (Łódź: Wydawnictwo UŁ 1979).

Kręcidło, J., „Świat pogański wobec rodzącego się chrześcijaństwa. Dlaczego chrześcijanie nie byli lubiani w starożytnym świecie?”, Ex oriente Lux. Księga pamiątkowa dla Księdza Profesora Antoniego Troniny w 65. rocznicę urodzin (red. W. Chrostowski) (Warszawa: Verbinum 2010) 82-291.

Kumaniecki, K., Historia kultury starożytnej Grecji i Rzymu (Warszawa: PWN 1988).

Kuźmak, K., „Imię Maryja. III. Bractwa”, Encyklopedia katolicka (red. S. Wielgus et al.) (Lublin: TN KUL 1997) VII, 67-68.

Leon-Dufour, X. (red.), Słownik teologii biblijnej (tł. i opr. K. Romaniuk) (Poznań: Pallottinum 1994).

Maciołka, M., „Imię Maryja. II. W liturgii”, Encyklopedia katolicka (red. S. Wielgus et al.) (Lublin: TN KUL 1997) VII, 67.

Malina, A., „Kobiety w genealogii Jezusa (Mt 1,1-17)”, Verbum Vitae 19 (2011) 109-129.

Marcus Aurelius, Meditationes, tł. B. Pawlak - M. Reiter: Marek Aureliusz, Rozmyślania (Gliwice: Helion 2016).

Martin, L.H., „Graeco-Roman Philosophy and Religion”, The Early Christian World (red. Ph.F. Esler) (London: Routledge 2002) 53-79.

Mazurkiewicz, R., Z dawnej literatury maryjnej. Zarysy i zbliżenia (Kraków: Wydawnictwo Naukowe Uniwersytetu Pedagogicznego 2011).

Musiał, D., Antyczne korzenie chrześcijaństwa (Warszawa: Trio 2001).

O'Carroll, M., Theotokos. A Theological Encyclopedia of the Blessed Virgin Mary (Eugene, OR: Wipf \& Stock 1982).

Ordon, H., „Kobiety w genealogii Jezusa (Mt 1,1-17) a sytuacja Kościoła Mateuszowego”, „Niewiastę dzielna kto znajdzie?” (Prz 31, 10). Rola kobiet w historii zbawienia (red. A. Kubiś K. Napora) (Analecta Biblica Lublinensia 14; Lublin: Wydawnictwo KUL 2016) 247-256.

Origenes, Contra Celsum, tł. H. Chadwick: Origen, Contra Celsum (Cambridge: Cambridge University Press 1980).

Ovidius, Fasti (ed. J.G. Frazer) (Loeb Classical Library 253; Cambridge, MA: Harvard University Press 1931).

Ovidius, Metamorphoses (red. R. Ehwald) (Bibliotheca Scriptorum Graecorum et Romanorum Teubneriana; Leipzig: Teubner 1915).

Ovidius, Tristia (red. R. Merkel) (Bibliotheca Scriptorum Graecorum et Romanorum Teubneriana; Leipzig: Teubner 1911).

Pelikan, J., Mary Through the Centuries. Her Place in the History of Culture (New Haven, CT: Yale University Press 1998).

Peters, F.E., The Harvest of Hellenism. A History of the Near East from Alexander the Great to the Triumph of Christianity (London: Allen \& Unwin 1972).

Pindar, Pindari carmina cum fragmentis (red. B. Snell - H. Maehler) (Leipzig: Teubner 1989).

Plato, Symposium. Greek Text with Commentary by Kenneth J. Dover (Cambridge Greek and Latin Classics; Cambridge: Cambridge University Press 1980).

Platon, Dialogi (tł. W. Witwicki) (Libri Mundi; Warszawa: Verum 1993). 
Platon, Państwo, Prawa (tł. W. Witwicki) (Komorów: Antyk 2001).

Plinius, Historia naturalis (red. C. Mayhoff) (Bibliotheca Scriptorum Graecorum et Romanorum Teubneriana; Leipzig: Teubner 1892-1909) I-VI.

Podbielski, M., „Platon”, Literatura Grecji starożytnej. Prace historyczne, krasomówstwo, filozofia i nauka, literatura chrześcijańska (red. H. Podbielski) (Lublin: TN KUL 2005) 597-611.

Polaszek, E., Antyczny romans grecki (Wrocław: Ossolineum 1986).

Rahner, H., „Die Marienkunde in der lateinischen Patristik”, Katholische Marienkunde (red. P. Sträter) (Paderborn: Schöningh 1947) 137-182.

Reinsberg, C., Obyczaje seksualne starożytnych Greków (tł. B. Wierzbicka) (Gdynia: Uraeus 1998).

Rohde, E., Der griechische Roman und seine Vorläufer (Leipzig: Breitkopf \& Härtel 1914).

Rosen, H.B. (red.), Herodotus (Bibliotheca Scriptorum Graecorum et Romanorum Teubneriana; Leipzig: Teubner 1987-1997) I-II.

Rubin, M., Mother of God. A History of the Virgin Mary (New Haven, CT: Yale University Press 2010).

Ryś, G., Błogosławiona między niewiastami. Księga Judyty (Kraków: Salwator 2015).

Ryś, G., Rut Moabitka krewna Boga (Kraków: eSPe 2013).

Santorski, A., „Maryja w nauce Ojców Kościoła. (Główne ukierunkowania)”, Vox Patrum 15 (1988) 927-937.

Starowieyski, M., „Maryja w pierwszych wiekach Kościoła”, W Drodze 179 (1988) 3-13.

Starowieyski, M., „Najstarszy opis mariofanii”, Vox Patrum 15 (1988) 735-744.

Starowieyski, M., „Tytuł Theotokos w świadectwach przedefeskich”, Analecta Cracoviensia 16 (1984) 409-449.

Varro Terentius M., De lingua Latina X (red. D.J. Taylor) (Appleton, WI: Benjamins 1996).

Varro Terentius M., De re rustica, tł. W.D. Hooper - H.B. Ash: Cato, Varro, On Agriculture (Loeb Classical Library 283; Cambridge, MA: Harvard University Press 1934).

Vassilaki, M., Images of the Mother of God. Perceptions of the Theotokos in Byzantium (Aldershot: Cambridge University Press 2005).

Vergilius, Aeneis (red. W. Janell) (Bibliotheca Scriptorum Graecorum et Romanorum Teubneriana; Leipzig: Teubner 1936).

Winniczuk, L., Ludzie, zwyczaje i obyczaje starożytnej Grecji i Rzymu (Warszawa: PWN 1983).

Winniczuk, L., Twórczość poetek greckich (Warszawa: PWN 1956).

Wipszycka, E., Kościół w świecie późnego antyku (Warszawa: PIW 1994).

Xenophon, Oeconomicus, tł. D. Tymura: Ksenofont, Ekonomik (Warszawa: PIW 2020).

Zawadzki, A., „Kim jest oblubieniec w przypowieści o dziesięciu pannach (Mt 25,1-13)? Między tradycyjnymi a współczesnymi próbami zrozumienia”, The Biblical Annals 9/2 (2019) 355-396.

Zieliński, T., Hellenizm a judaizm (Warszawa: Mortkowicz 1927) I-II.

Zieliński, T., Literatura starożytnej Grecji epoki niepodległości (Warszawa: Mortkowicz 1923).

Zieliński, T., Religia starożytnej Grecji. Zarys ogólny. Religia hellenizmu (Wrocław: Ossolineum 1991).

Życiński, W., Matka, która pozostała dziewica (Kraków: Scriptum 2017). 